\title{
Foreign Direct Investment and Local Firm's Performance
}

\author{
M. D. Wanjere, M. Ogutu, M. Kinoti, and X. N. Iraki
}

\section{ABSTRACT}

\begin{abstract}
This paper investigates the effect of FDI on performance of manufacturing firms in Kenya. Little is documented about the link between FDI and performance of local firms in Kenya . The study has sought to establish the overall effect of FDI on the performance-manufacturing firms in Kenya. The population of study comprised 100 companies registered with Kenya Association Manufacturing as at the time of data collection in 2019 and that had over 10 percent foreign ownership. The respondents were the CEOs of organization. The study used a structured questionnaire to collect primary data. Descriptive and inferential statistics were both used to analyze the data. Data was pretested for normality, linearity, multicollinearity, autocorrelation and homoscedasticity and the data found to meet most of these preconditions. The study developed hypothesis which was tested using simple linear regression to establish the effect of FDI on performance of manufacturing firms. The results revealed that there was a statistically significant relationship between FDI and firm performance. This imply that to achieve better firm performance, the government need to come up with polices geared to attracting more FDI into the key sectors of the economy.
\end{abstract}

Keywords: Foreign Direct Investment, Firm Performance.

\author{
Submitted : November 292021 \\ Published : December 29, 2021 \\ ISSN: $2507-1076$ \\ DOI: $10.24018 /$ ejbmr.2021.6.6.1181 \\ M. D. Wanjere * \\ School of Business, University of Nairobi, \\ Kenya. \\ (e-mail: mdwanjere@gmail.com) \\ M. Ogutu \\ School of Business, University of Nairobi, \\ Kenya. \\ (e-mail: ogutum@uonbi.ac.ke ) \\ M. Kinoti \\ School of Business, University of Nairobi, \\ Kenya. \\ (e-mail: m.kinoti@uonbi.ac.ke) \\ X. N. Iraki \\ School of Business, University of Nairobi, \\ Kenya. \\ (e-mail: xniraki@gmail.com) \\ *Corresponding Author
}

\section{INTRODUCTION}

Availability of credit is a major constraint to Sub-Saharan Africa according to IMF (2018). Evidence point to the fact that the region has the highest share of firms that require loans to develop but cannot access credit from banks. Further banks in Sub-Saharan Africa do not finance investment as they do in other areas. Leman and Ismet (2015) noted that FDI inflows are among the easiest ways of closing capital deficiencies in developing countries as well as providing them with technological know-how. Muli, Aduda, Lishenga and Abala (2017) argued that developing countries use foreign direct investment (FDI) to supplement their low levels of national savings in order to promote economic development. capital and managerial expertise.

Over the years, developing countries have adopted policies to attract foreign investment in the hope that domestic economy would benefit from it. (Yi, Zhigang and Lianming, 2017). Attracting foreign investment is a major policy priority as foreign investment has important complementarities with local industry. Newman, Rand, Talbot and Tarp (2015) apprises that Multinational Enterprises (MNEs) presents high capability firms to low capability industrial setting and given an implicit assumption of automatic diffusion mechanisms, spillover occur from MNEs to local firms.

Sub-Sahara African (SSA) countries lack viable technological capacity needed to spur economic growth in this region. These countries have made attempt to upgrade their skills and technologies through importation of capital goods, investment in appropriate research and development, learning of new technologies through exporting, and foreign direct investment (FDI) usually associated with the activities of multinational firms. Nevertheless, it is apparent that for many SSA countries, several of the channels by which modern technologies can be acquired has been unsuccessful leaving them in a technologically constrained position with regard to their capacity to industrialize. (Onyekwena, 2012).

\section{A. Kenya's Manufacturing Sector}

The Kenya's Manufacturing Sector is a fundamental channel for promoting the country's integration into the regional and international markets, as well as, a major source of job opportunities. Bivens study, (citied in KAM, 2018) suggested that about 100 jobs in the manufacturing sector supports either directly or indirectly 291 jobs in other sectors of the economy. This in itself demonstrates the enormity of economic development a country can enjoy with a robust manufacturing sector. However, the contribution of the sector has stagnated at less than 10 percent with a premature deindustrialization as evidenced by the decline in GDP contribution by the sector to 4.2 per cent in 2016 (KAM, 2018). Furthermore, credit to manufacturing sector contracted by 4.6 per cent from KSh 290.9 billion in 2015 to KSh 277.4 billion in 2016.

Despite the importance of the manufacturing sector for the Kenyan economy and the increased flow of FDI into the sector, FDI's effects on domestic firms in the Kenyan 
manufacturing industry have not been systematically studied making sector a suitable context to examine the link between FDI and firm's performance. A number of researchers (Busienei, K’Obonyo \& Ogutu, 2013, Okeyo, 2013) used manufacturing sector in their study. The study will analyze spillovers that foreign firms have on domestic ones in the Kenya manufacturing sector.

\section{THEORETICAL AND EMPIRICAL LITERATURE}

A fundamental feature of the neoclassical trade theories is the recognition that externalities and spillovers have always occurred on a firm-level basis. Put forward by the Mundell (1957), the theories argue that imposition of trade restrictions creates a favorable channel for production factors to spill over across borders. Kindelberger (1969) terms these transfers as direct investments. However, it is important to note that the spillovers are not prompted by disparities in production factors as claimed by Hymer (1960) (as cited in Hymer 1976) but rather the need to reap the benefits that may accrue from investments in others. The theories also recognizes that the classic strategic advantages poise companies to attract huge direct investments and that the involved investors operate in an extremely oligopolistic fashion. This implies that MNCs that are devoid of such advantages facilitate the transmission of production capabilities to the companies in the host region.

There's a lot of emphasis on studies of foreign direct investment largely on account of its potential benefits to host countries. Dadzie (2012) pointed out that foreign direct investment is instrumental for the growth of local firms as it provides investment funds, create competition, increase their productivity through adoption of better technologies or investing in human and/or physical capital. Onyekwena, (2012) asserted that studies on foreign direct investment spillover assumes that technologies are freely available to local organization and that FDI automatically involve transfer of technology and therefore local firm's benefits automatically. Pedro, Jorge and Jose (2014) established that spillover from MNCs is a source of technical progress and thereby contributes to overall firm performance. Newman, Rand, Talbot \& Tarp (2015) evaluated the relationship between technology transfer, foreign investment and productivity spillover and empirically established that certain gains in productivity were linked to direct connection between domestic and foreign owned companies along supply chain. Lugemwa (2014) finds that FDI plays an important role in fostering growth of local manufacturing firms.

Leman and Ismet, (2015) noted that FDI inflows has been the main source of economic growth among developing countries. Multinationals a key FDI vehicle, invest in R\&D laboratories, leading to new technologies, new products and production processes, new patent and acceleration of innovation activities within host countries. Thus, FDI promote the growth of local firms that produce local intermediate products and services, which in turn, boosts the overall development of firms that deal with production of final products. Ilboudo (2014), study on FDI and Total Factor Productivity empirical results indicated a positive sign for FDI meaning FDI positively contributes to an increase in productivity. Further, Byung and Shufeng (2015) established that the association between FDI and productivity of domestic firms has an inverted U-shaped distribution in the data, where productivity rose up to a certain point, beyond which it reduced as the FDI increased.

In contrast, Gui-Diby (2014) claims that FDI inflow has a negative association effect on economic growth because majority of the host countries have poor business environments and do not tap technology in the right way. Further, a hypothesis that FDI accelerated productivity growth in domestic firms was rejected in Mexico, as seventyone (71) per cent of such investment was meant for purchasing already existing Mexican companies and did not necessarily lead to capital formation (Muhammad and Kashif, 2013). Whereas some of the literature demonstrated positive and significant relationships between FDI and firm performance, others clearly contradicted this view by either indicating negative effect or non-existence. It is this mixed and inconclusive position which drove the study to evaluate the impact of FDI on the performance of Kenyan manufacturing firms.

Damgaard (2011) study on analysis of total productivity spillover established a statistically significant negative spillover effect at the cumulative level. However, the study asserted that results differed widely across industries with firm's high export orientation and those in competitive environments experiencing less negative spillovers. Further, Pavlınek and Zizalova (2014) affirmed that local firms were vulnerable to positive and negative spillovers. The negative horizontal spillovers emanated from failure to eliminate crowding out phenomena forcing most local companies to be purchased or engage in joint arrangements with foreign companies and in the worst cases close business. Barrios, Görg and Strobl (2006) observed an insignificant link between these spillovers and performance of local companies in East-Central Europe. Further, entry of FDI resulted to temporal negative horizontal spillover (Pavlinek and Zuzalova, 2014). Renzi (2012), study on the impact of multinational corporations on the South African economy established mixed results.

\section{CONCEPTUAL FRAMEWORK AND HYPOTHESIS}

\section{A. Conceptual Framework}

Conceptual framework denotes a set of broad thoughts and values extracted from relevant spheres of study and adapted in configuring a sub-sequent presentation (Kombo and Tromp, 2009). The study conceptualized that FDI influences firm performance. The framework is illustrated in Fig. 1.

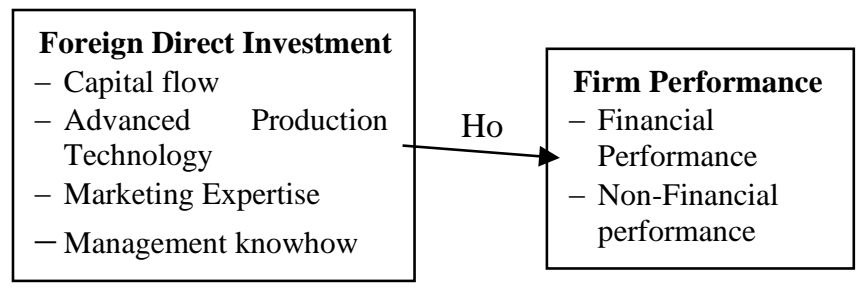

Fig. 1. Conceptual framework. Source: Researcher 2017. 


\section{B. Conceptual Hypotheses}

The hypotheses was derived from the research objectives and the conceptual framework and was stated as follows:

Hypothesis: Foreign direct investment has no significant effect on the performance of local manufacturing firms in Kenya.

\section{Methodology AND DATA}

This research adopted a cross-sectional design to evaluate relationship among variables in the study and data was collected from various organizations at a single point in time and analyzed according to set hypotheses. The study population consisted of all the 100 manufacturing firms registered with KAM and that had over $10 \%$ foreign investment in Kenya. The firm was the principal unit under investigation.

The study operationalised independent variable FDI using four broad categorizations, namely capital flow, advanced production technology, marketing expertise and management knowhow (Muhammad and Kashif, 2013). The dependent variable of this study was firm's performance and was assessed using financial (profitability and ROE) and nonfinancial (capacity utilization and employee's productivity) indicators of firm performance.

The data was collected from one member of the top management preferably CEO or the finance and strategy director who were considered knowledgeable about the issue under investigation; as such, they were the main informants. Their choice is consistent with similar studies conducted by Shabarati, Jawad and Bontis (2010) and Cabrita and Bontis (2008) who claim top managers are knowledgeable about organizational characteristics.

Both descriptive and inferential statistics were utilized to analyze the data. Descriptive statistics was computed to represent general information and firm characteristics (Kothari, 2014). Additionally, a series of regression analyses was conducted to assess the relationship between the independent and dependent variables to determine whether the results are significant or not. Table I provides a summary of the hypothesis test and analytical procedures.

\section{PRELIMINARY ANALYSIS}

\section{A. Diagnostic Test}

1) Histogram Graphs for Normality of Responses

1.1) Foreign Direct Investment
Fig. 2 displays a symmetrical histogram, an indication that foreign direct investment was normally distributed. Specifically, the variable followed a normal distribution with a mean equal to 2.46 and standard deviation of 0.311 . As such, it was concluded that the foreign direct investment variable met the normality condition.

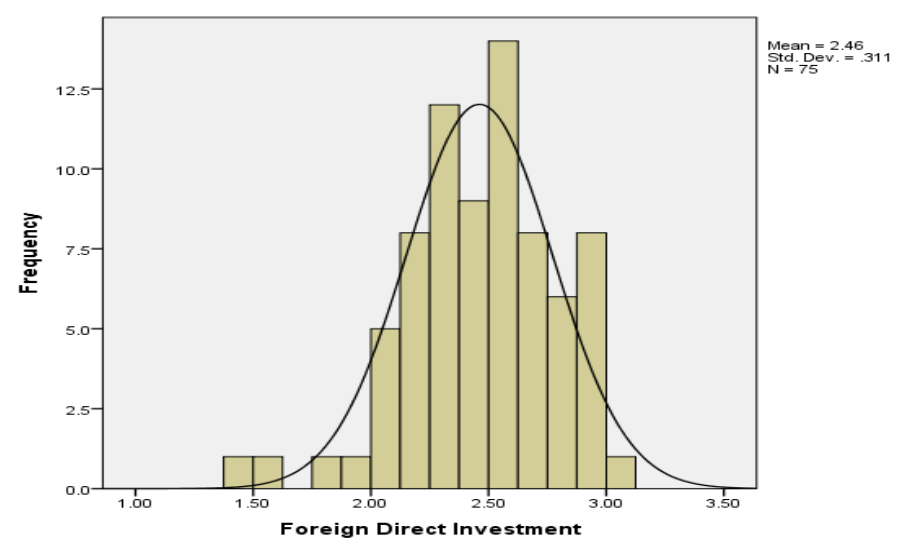

Fig. 2. Histogram of Foreign Direct Investment. Source: Field Data 2019.

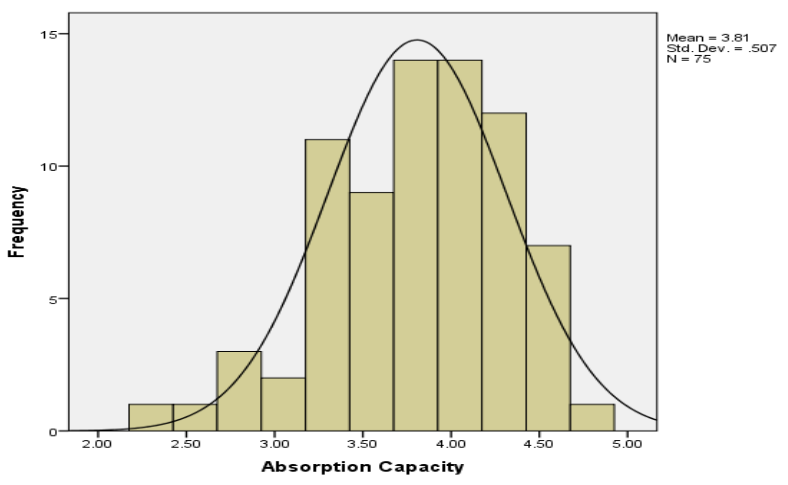

Fig. 3. Histogram of Absorptive Capacity.

\section{2) Manufacturing Performance}

The manufacturing firm performance variable was investigated for normality using histogram and results of analysis presented in Fig. 3 below.

Fig. 3 is a symmetrical histogram indicating that the independent variable manufacturing firm performance was normally distributed. Manufacturing firm performance as a response variable provided responses that upon exploring for normality showed that the responses on manufacturing performance were normally distributed and the histogram was bell-shaped about a mean equal to $2.77(S D=0.52)$. As such there is evidence to conclude that the data for manufacturing firm performance did not deviate from normality.

TABLE I: OBJECTIVES, HyPOTHESES, TESTS AND ANALYTICAL MODELS

\begin{tabular}{|c|c|c|c|}
\hline Objective & Hypothesis & Hypothesis Test & Analytical model \\
\hline $\begin{array}{c}\text { Objective: } \\
\text { Establish the } \\
\text { effect of FDI } \\
\text { on firm's performance. }\end{array}$ & $\begin{array}{l}\text { Ho: FDI has no significant } \\
\text { effect on firm's } \\
\text { performance. }\end{array}$ & $\begin{array}{c}\text { Simple regression analysis } \\
\mathrm{FP}=\beta 0+\beta 1 \mathrm{FDI}+\varepsilon \ldots \text { Where } \\
\mathrm{FP}=\text { Firm performance } \\
\beta 0=\text { Constant (intercept), } \\
\beta 1=\text { Regression coeff. for FDI } \\
\text { FDI=Composite index of FDI } \\
\varepsilon=\text { Error term }\end{array}$ & $\begin{array}{l}\text { Coefficient of determination } \\
\text { (adjusted } \mathrm{R}^{2} \text { ) value show the } \% \\
\text { of firm performance explained } \\
\text { by FDI. Regression coefficient will } \\
\text { show the amount of change } \\
\text { s\& direction of the influence }\end{array}$ \\
\hline
\end{tabular}

Source: Field Data 2019. 


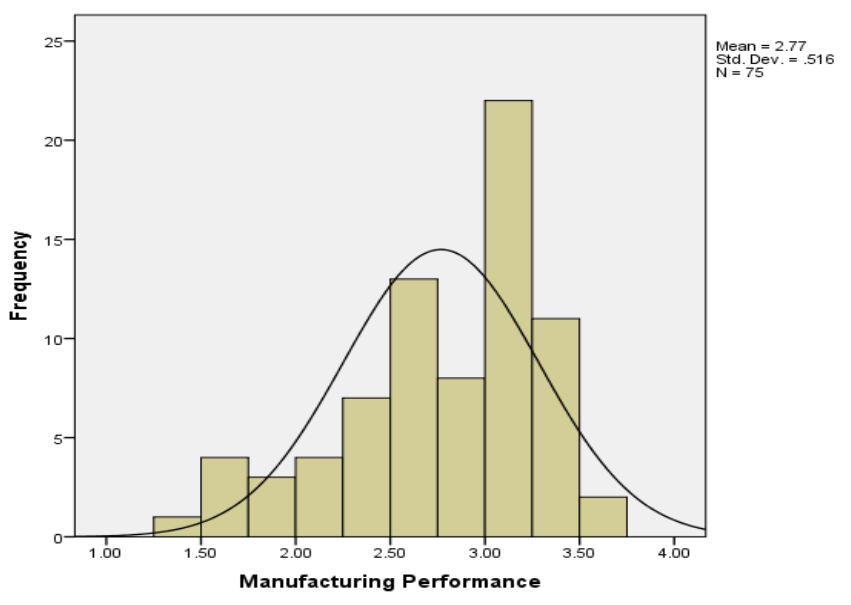

Fig. 4. Histogram Of Firm Performance. Source: Field Data 2019.

\section{2) Multicollinearity Test}

Multicollinearity occurs when there are multiple explanatory variables that exhibit high degree of correlations (Mugenda and Mugenda, 2003; Zientek, Kim and Amanda, 2016). In order to check for this precondition, the variance inflation factor (VIF) test was invoked. Based on this test, a VIF exceeding 10 is indicative of multicollinearity (Hair, Anderson, Tatham and Black, 2008). The results of this test are presented in Table II.

TABLE II: COLLINEARITY STATISTICS

\begin{tabular}{lcc}
\hline \multicolumn{2}{c}{ Variable } & \multicolumn{2}{c}{ Collinearity Statistics } \\
\cline { 2 - 3 } & Tolerance & VIF \\
\hline Foreign Direct Investment & 0.984 & 1.016 \\
\hline $\begin{array}{l}\text { Dependent Variable: "Manufacturing Performance. } \\
\text { Source: Field Data (2019) }\end{array}$
\end{tabular}

Table IV shows that for the three variables of interest, the VIF was 1.016. The values being more than 1 and less than 10 indicate that there was absence of multicollinearity. Additionally, the tolerance values was 0.984 further confirming non-violation of the precondition.

\section{3) Homogeneity Tests}

Homoscedacity test is done to examine whether the different values of responses have the same variances regardless of values of the predictor variable. Homoscedasticity assumption means that standard deviation and variance of errors about the regression line is unvaried for all the explanatory variables (Tabachnick and Fidell, 2013) and that the residuals are rectangular distributed around the predicted dependent variable and are more concentrated around the center (Pallant, 2005).

The levene test was used to assess this precondition. This test examines whether or not the null hypothesis that there is no equality in the variances of two populations is true (Hair, Anderson, Tatham and Black, 2008). For the purpose of this study, this test was grounded on a 5\% significance level. The results of the test are as shown in Table III.

TABLE III: LEVENE TEST STATISTICS

\begin{tabular}{ccccc}
\multicolumn{6}{c}{ TABLE III: LEVENE TEST STATISTICS } \\
\hline Variable & Levene Statistic & df1 & df2 & Sig. \\
\hline $\begin{array}{c}\text { Foreign Direct } \\
\text { Investment }\end{array}$ & 2.733 & 12 & 58 & 0.005 \\
\hline Source: Field Data (2019). & & & &
\end{tabular}

Table III shows that FDI had a $p$-value of less than 0.05 . Therefore, the null hypothesis that the data for foreign direct investment did not fulfil the homoscedasticity condition was accepted. Based on the $p$-values, it was concluded that foreign direct investment did not meet the precondition.

\section{B. Descriptive Statistics}

Descriptive statistics were useful in this study as they presented quantitative data in a manageable form. The findings are presented in the next section.

\section{1) Foreign Direct Investment}

In this study FDI was conceptualised using four variables namely: capital flow, advanced production technology, marketing expertise and management knowhow as guided by Muhammad and Kashif (2013) and Leman and Ismet (2015). The respondents were required to respond by indicating if FDI introduction led to certain activities associated with the capital flow, advanced production technology, marketing expertise and management knowhow in their organizations. The findings are presented in Table IV.

TABLE IV: FOREIGN DIRECT INVESTMENT

\begin{tabular}{cccccc}
\hline Variables & $\mathrm{N}$ & Mean & $\begin{array}{c}\text { Std. } \\
\text { Deviation }\end{array}$ & $\begin{array}{c}\text { Varianc } \\
\mathrm{e}\end{array}$ & $\mathrm{CV}$ \\
\hline $\begin{array}{c}\text { Foreign Direct } \\
\text { Investment }\end{array}$ & 75 & 2.47 & 0.82 & 0.685 & $\begin{array}{c}0.312 \\
5\end{array}$ \\
\hline Source: Field Data (2019). & & & &
\end{tabular}

Foreign Direct Investment was a mean score of 2.47, std deviation of 0.82 , variance of 0.68 and $\mathrm{CV}$ of 0.3125 . On specific variable, the highest ranked was capital flow with a score (mean scores above 2.68, standard deviation of 0.70 .

\section{2) Manufacturing Performance}

The extant literature indicates that firm's performance is a multidimensional variable as such no single index can offer a comprehensive understanding therefore it is imperative to consider multiple measures (Frank, Kessler \& Fink, 2010). The performance of the manufacturing companies was considered from two angles, that is, financial and nonfinancial outcomes. With respect to the financial aspect, profits and return on equity were considered. On the other hand, non-financial outcomes involved production capacity utilization and employee productivity. The financial performance of the surveyed firms was gauged in terms of how much profits they had attained in 2018 as well as their reported return on equity. The outcomes are displayed in Table V.

TABLE V: PROFIT ACHIEVED IN 2018

\begin{tabular}{ccc}
\hline Profit per year in Kenya Shillings Mill & Frequency & Percent \\
$(2018)$ & 5 & 6.7 \\
\hline Losses & 12 & 16.0 \\
0 to 100 Million & 41 & 54.7 \\
Above 100 Million to 200 Million & 15 & 20.0 \\
Above 200 Million to 300 Million & 2 & 2.7 \\
Above 300 Million & 75 & 100.0 \\
\hline Total & & \\
\hline
\end{tabular}

Source: Field Data (2019).

It is apparent that 6.7 percent of the companies made losses. During the same period, 16 percent of the firms attained profits of up to Kshs 100 million, 54.7 percent attained profits of between Kshs 100 million and 200 million, 20 percent had profits of between Kshs 200 million and 300 
million while 2.7 percent of the firms had profits exceeding Kshs 300 million. The results imply that a large proportion of the FDI manufacturing firms were profitable. This is consistent with Ilboudo (2014) study that established that FDI positively contributes to an increase in productivity of local firms.

\section{3) Return on Equity}

The analysis of data shows that $49.3 \%$ of the surveyed companies had a return on equity of between $4 \%$ and $8 \%$ in the year. $25.3 \%$ had ROE of between $8-12 \%, 9.3$ percent had a ROE of above $12 \%$, and another $9.3 \%$ had a return of between $0-4 \%$ and $6.7 \%$ had a negative ROE. These results were consistent with KAM manufacturing barometer report that had projected growth rates of between 1-11 percent (KAM, 2019). The outcomes are displayed in Table VI below.

TABLE VI: RETURN ON EQUITY

\begin{tabular}{ccc}
\hline Return on Equity (2018) & Frequency & Percent \\
\hline Negative & 5 & 6.7 \\
$0-4 \%$ & 7 & 9.3 \\
Above $4 \%$ to $8 \%$ & 37 & 49.3 \\
Above $8 \%$ to $12 \%$ & 19 & 25.3 \\
Above $12 \%$ & 7 & 9.3 \\
\hline Total & 75 & 100 \\
\hline
\end{tabular}

Source: Field Data (2019).

\section{4) Regression Analysis}

The researcher set out to test the effect of FDI on performance of manufacturing firms. The study developed a hypothesis and this was tested using simple linear regression analysis. The hypothesis was stated as follows.

\section{$H_{O}$ : There is no statistically significant influence of FDI on performance of manufacturing firms in Kenya.}

To test this hypothesis, a composite score for FDI that combined it's four components was first computed and then regressed on the performance index of the companies. The results are displayed in Table VII.

\section{Discussion of Results}

Foreign Direct Investent and Performance of Manufacturing Firms

From the results, when FDI is regressed against firm's performance, it accounted for $7.9 \%$ of the variation in performance as illustrated in Table VII. The results also demonstrate that the explanatory power of the model was significant $(F(1,73)=6.28, p<0.05)$. Additionally, the model furnished a significant coefficient for the FDI variable $(\beta=0.467, p<0.05)$. Since the coefficient was positive, the implication is that unit increment in FDI would boost performance by $46.7 \%$. The results further substantiate the proposition that the combinatory effect of FDI components on performance supersedes that of the individual effect of capital flow, advanced production technology, marketing expertise and management knowhow.

These findings are consistent with a study by Leman and Ismet (2015) who noted that FDI inflows are among the easiest ways of closing capital deficiencies in developing countries. The findings of the study also concur with Pedro, Jorge and Jose (2014) evaluated the effects of foreign capital on Spanish manufacturing firms and established that FDI had positive spillovers on local firms. They noted that when the foreign capital was large enough, it promoted technical progress of the host economies.

Foreign direct investment inflows have enabled recipient countries to accumulate capital, acquire know-how, and new technological practices that have improved their levels of innovativeness and even promote economic growth (Temiz and Aytac, 2014; Asuantri and Yasmin, 2017). The current study further supports Görg and Strobl (2001) findings that through the establishment of relationships with local suppliers, Multinationals impact the performance of Irish companies positively.

Further the findings support Nadide and İbrahim (2014) study that established that FDI contributes to economic development by increasing capital buildup and technology improvements which in turn improves the performance of firms. They noted that capital accumulation leads to investment in the innovation of new concepts and skills, and since knowledge is to some extent a public good, it increases the level of technology not only within the organization but in the whole country. The current findings also agree with Wang, Deng, Kafouros, and Chen (2012) study, which found that different foreign entry modes had a considerable impact on the scope of foreign presence and the productivity outputs of companies in the host country. Additionally, the findings are also in agreement with Lugemwa (2014) who recognized FDI as a critical aspect when it comes to driving growth of the manufacturing sector.

TABLE VII: INFLUENCE OF FDI ON PERFORMANCE

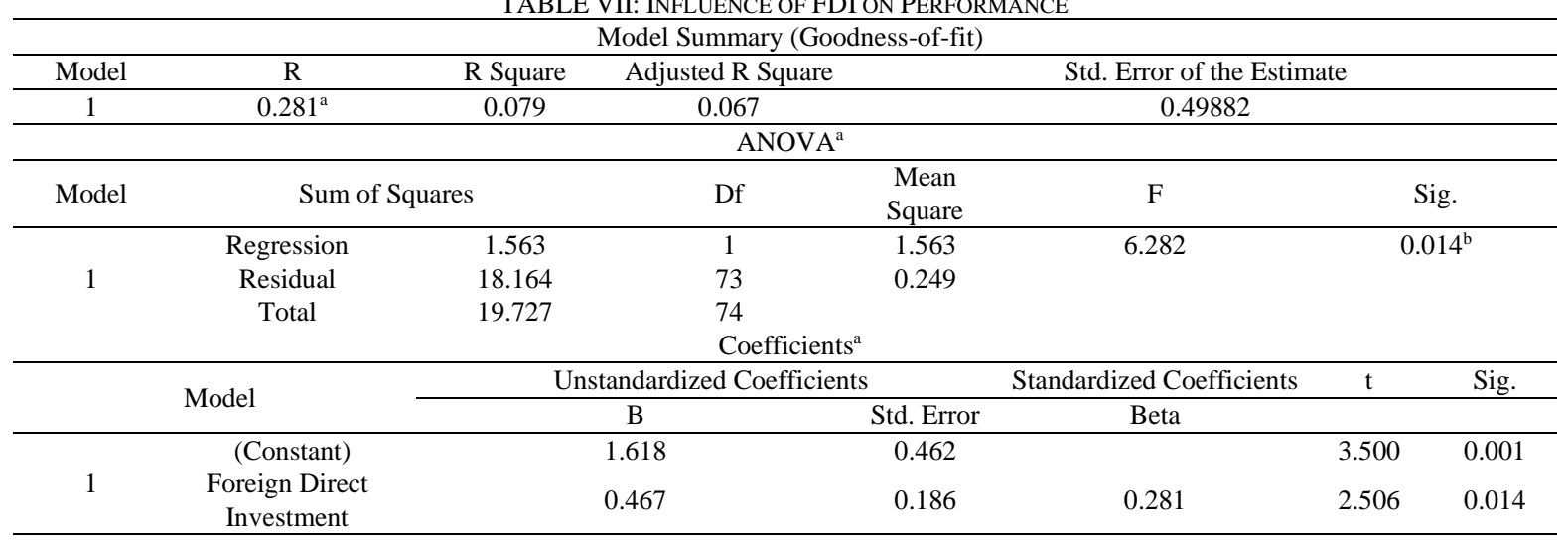

a. Dependent Variable: Manufacturing Performance.

b. Predictors: (Constant), Foreign Direct Investment.

Source: Field Data (2019). 
The study further supports IMF (2018) observation that foreign direct investment benefits does not appear as expanded resources that can be invested, but it also appears in sharing of knowledge and technology. The findings concur with the Government of Qatar, (2014) that observed that FDI encourage partners to transfer know-how and technology and also provide opportunities specially to host countries to promote their products in the global market giving them market access. The study is also consistent with Marco and Claudia, (2014) assertion that multinationals invest in low product cost countries and then serve domestic and foreign markets giving these countries access to foreign markets.

On the other hand, results of this study were contrary to Gui-Diby (2014) study findings that had earlier established that foreign direct investment inflow produces a reverse effect on economic growth. It also contradicts the study by Diyamett and Mutambla (2014) study on Tanzanian firms found that very few firms acknowledged FDIs as their sources of knowledge for technological abilities attained, a fact supported by their limited connections with foreign investors. The current findings are also inconsisted with Muhammad and Kashif, (2013) which rejected the hypothesis that foreign direct investment accelerated efficiency growth in domestic firms in Mexico, as seventy-one (71) per cent of such investment was meant for purchasing already existing Mexican companies and did not necessarily lead to capital formation.

\section{CONCLUSION}

The objective of the study was to establish the effect of FDI on performance of manufacturing firms in Kenya. The results revealed that there was a statistically significant relationship between FDI and firm performance. Based on the results, it can be concluded that FDI has positive effect on firm performance of manufacturing firm.

The findings enrich the understanding of the theory of FDI, which has been helpful in explaining the flow of FDI. Further, the findings lend credibility to the burgeoning empirical bases that demonstrate the salience of FDI in the elevation of developing economies. This implies that developing countries stand to gain more if they put measures geared to attracting FDI.

Kenyan and Sub-Sahara Africa countries policy makers are informed by the findings of this study that FDI is an important ingredient in stimulating the performance of local firms. Therefore, there is a need to continue attracting FDI to support the growth of local economies. The policy makers in these countries should focus increasing the amount of FDI going to the manufacturing sector because an increase in FDI catalyzes the growth of local firms.

\section{ACKNOWLEDGEMENTS}

We wish to profoundly acknowledge the organizations that made the access of data possible namely the Kenya Association of Manufacturer and Kenya Export Promotion. Center and the many manufacturing firms that participated in the study. We thank you all!

\section{REFERENCES}

Asuantri, M., and Yasmin, B. (2017). Foreign Direct Investment, absorptive capacity and technological innovation: Empirical evidence in developing economies. Global conference on business \& economics research. Online www.econ.upm.edu.my.

Barrios, S., Görg, H., and Strobl, E. (2006), Multinationals' Location Choice, Agglomeration Economies, and Public Incentives, International Regional Science Review, 29(1), 81-107.

Busienei JR, K'Obonyo, Ogutu, M., (2013). The Effect of Human Resource Strategic Orientation on Performance of Large Private Manufacturing Firms in Kenya. Prime Journal of Business Administration and Management (BAM)., 3(1), 834-857

Byung, P. and Shufeng, X. (2015), When Do Local Firms Benefit from Inward Foreign Direct Investment? A Longitudinal Study of China's Manufacturing Sector Covering 1998-2007, Thunderbird International Business Review, 58(4).

Cabrita, R., and Bontis, N. (2008). Intellectual capital \& business performance in Portuguese banking industry. International Journal of Technology Management, 43, 212-237.

Dadzie, R.B. (2012). Developmental State and Economic Development: Prospects for Sub-Saharan Africa, Journal of Sustainable Development; 5(9).

Damgaard, J. (2011), Measuring FDI \& its Impact on the Danish Economy; unpublished PhD Thesis, University of Southern Denmark.

Diyamett, B., and Mutambla, M. (2014). Foreign Direct Investment and Local Technological Capabilitie in least developed countries: some evidence from the Tanzanian Imanufacturing sector. African Journal of Science, Technology, innovation and Development, 16(5).

Gui-Diby, S.L. (2014). Impact of foreign direct investments on economic growth in Africa: Evidence from three decades of panel data analyses. Research in Economics, 68, 248-256.

Görg, H., and Strobl, E. (2001). Multinational companies and productivity spillovers: A meta-analysis. Economic Journal, 111(475), 723-739.

Government of Qatar (2014). Foreign Investment Survey, 2013, Published by Ministry of Development Planning and Statistics State of Qatar, Doha.

Hair, J. F., Anderson, R. E., Tatham, R. L., and Black, W.C. (2008). Multivariate data analysis, 5th Edition, Upper Sadddle River: NJ, Prentice Hall.

Hymer, S. (1976). The International Operations of National Firms, Ph.D. Thesis, Cambridege, MA: MIT ress.

Ilboudo, P. S. (2014). Foreign Direct Investment and Total Factor Productivity in the Mining Sector: The case of Chile. Economics Honors Papers. 18.

International Monetary Fund, (2018). Private Investments to Rejuvenate Growth. Regional Economic Outlok; sub-Sahara Africa, Washington DC, April.

Kenya Association of Manufacturers. (2018). Manufacturing in Kenya Under the 'Big 4 Agenda' A Sector Deep-dive Report. Publication of Kenya Association of Manufacturers, Kenya.

Kindleberger, C.P. (1969). American Business Abroad. Yale University Press, New Haven, CT, United States.

Kombo, D. K., \& Tromp, L. A. (2009). Proposal and thesis writing: An introduction. Nairobi: Paulines publications Africa.

Kothari, C. R. (2014). Research Methodology: Methods and Techniques. New Delhi, India: New Age International Publishers. Second revised edition

Leman, E., and Ismet, G., (2015). The Effects of Foreign Direct Investment on R\&D and Innovations: Panel Data Analysis for Developing Asian Countries. World Conference on Technology, Innovation and Entrepreneurship. Procedia-Social and Behavioral Sciences 195, pp.749-758. Online at www.sciencedirect.com.

Lugemwa, P. (2014). FDI and SME Growth: Highlighting the Need for Absorptive Capacity to Support Linkages between Transnational Corporations and SMEs in Developing Countries. International Journal of Economics, Finance and Management Sciences. 2(4), 245-256.

Mugenda, O. M. and Mugenda, A. G. (2003). Research Methods. Quantitative and Qualitative Approaches. Nairobi: African Centre for Technology Studies Press.

Muhammad, T. M., and Kashif, R. (2013). Does Foreign Direct Investment Influence Economic Growth and Human Capital of Host Countries? A Review of Empirical Evidence. World Applied Sciences Journal, 21 (8), 1116-1121.

Muli, W.M., Aduda, J.O., Lishenga, J.L., and Abala, D.O. (2017). The Moderating Effect of Economic Growth on the Relationship between Economic Integration and Foreign Direct Investment in the East African Community: Journal of Finance and Investment Analysis, 6 (3), 85-114. Mundell, R.A. (1957). International trade and factor mobility, American Economic Review, 47(3), 321-335. 
Nadide, S. T. and İbrahim, D. (2014). The Impact of Foreign Direct Investments on SMEs' Development/Procedia - Social and Behavioral Sciences, 150, 107-115.

Newman, C., Rand, J., Talbot, T., and Tarp, F. (2015). Technology transfer, foreign investment and productivity spillover, European Economic Review, 76, 168-185.

Onyekwena, C. (2012), Empirical investigation of the impact of Foreign Direct Investment on manufacturing firms and banks in Nigeria, Unpublished PhD Thesis, University of Portsmouth.

Pedro S.S., Jorge R.M., \& Jose, G.G.V. (2014). Absorptive capacity from FDI in Spanish Manufacturing firms, International Business Review, Elsevier, vol. 23(2), 429-439.

Pavlinek, P.; and Zizalova, P. (2014). Linkages and spillovers in global production networks: firm-level analysis of the Czech automotive industry; Journal of Economic Geography, 16, 331-363.

Renzi, L. (2012). The impact of multinational corporations on the South African economy, unpublished MBA dissertation, University of Pretoria, Pretoria.

Shabarati, A., Jawad, J. and Bontis, N. (2010). Intellectual capital and business performance in pharmaceutical sector of Jordan. Management Decision Journal, 48 (1), 105-13.

Tabachnick, B.G., and Fidell, L.S.,(2013). Using multivariate statistics, $\left(6^{\text {th }}\right.$ ed.). Boston: Pearson.

Temiz, D., and Aytaç, G. (2014). FDI inflow as an international business operation by MNCs and economic growth: An empirical study on Turkey, International Business Review, 23, 145-154

Wang, C., Deng, Z., Kafouros, M., and Chen, Y., (2012). Reconceptualizing the spillover effects of foreign direct investment:A process-dependent approach. International Business Review, Elsevier, 21(3), 452-464.

Yi, L. Zhigang, T. and Lianming, Z. (2017). Identifying FDI Spillovers. Journal of International Economics, 107, 75-90. 